BASINDO : Jurnal Kajian Bahasa, Sastra Indonesia, dan Pembelajarannya

Volume 2 Nomor 1, 2018

Journal homepage : http://journal2.um.ac.id/index.php/basindo

\title{
PENDIDIKAN KARAKTER ANAK AUTIS MELALUI DONGENG
}

\author{
Endang Sumarti* \\ IKIP Budi Utomo Malang, Indonesia
}

\begin{tabular}{|c|c|}
\hline A R T ICLE INFO & A B S T R AC T \\
\hline $\begin{array}{l}\text { Keyword: } \\
\text { pendidikan karakter, } \\
\text { anak autis, } \\
\text { dongeng }\end{array}$ & $\begin{array}{l}\text { Pendidikan karakter merupakan bentuk kegiatan manusia yang di dalamnya terdapat } \\
\text { suatu tindakan yang mendidik diperuntukkan bagi generasi selanjutnya. Tujuan } \\
\text { pendidikan karakter adalah untuk membentuk penyempurnaan diri individu secara terus- } \\
\text { menerus dan melatih kemampuan diri menuju hidup yang lebih baik. Pendidikan karakter } \\
\text { dibutuhkan anak autis sebagai bekal dalam hidupnya sehingga siap menghadapi segala } \\
\text { tantangan di dunia yang penuh persaingan dengan penuh percaya diri. Salah satu cara } \\
\text { penanaman nilai pendidikan karakter anak autis dilakukan melalui dongeng. Dongeng } \\
\text { merupakan media efektif untuk menanamkan nilai pendidikan karakter kepada anak autis. }\end{array}$ \\
\hline
\end{tabular}

\section{PENDAHULUAN}

Pendidikan karakter merupakan bentuk kegiatan manusia yang di dalamnya terdapat suatu tindakan yang mendidik diperuntukkan bagi generasi selanjutnya. Pendidikan karakter, pendidikan budi pekerti dapat dikatakan sebagai proses untuk penyempurnaan diri manusia, merupakan usaha manusia untuk menjadikan dirinya sebagai manusia yang berakhlak mulia, manusia yang berkeutamaan (Koesoema, 2007). Pendidikan karakter pada prinsipnya adalah upaya untuk menumbuhkan kepekaan dan tanggung jawab sosial, membangun kecerdasan emosional dan mewujudkan siswa yang memiliki etika tinggi (Barnawi, 2012). Amanat Undang-undang Nomor 20 tahun 2003 Pasal 3 tentang Sistem Pendidikan Nasional secara tegas menyatakan bahwa pendidikan nasional berfungsi mengembangkan kemampuan dan membentuk watak serta peradaban bangsa yang bermartabat dalam rangka mencerdaskan kehidupan bangsa, bertujuan untuk berkembangnya potensi peserta didik agar menjadi manusia yang beriman dan bertakwa kepada Tuhan Yang Maha Esa, berakhlak mulia, sehat,berilmu, cakap, kreatif, mandiri, danmenjadi warga negara yangdemokratis serta bertanggungjawab.

Pendidikan karakter sebagai sebuah usaha untuk mendidik anak-anak agar dapat mengambil keputusan dengan bijak dan mempraktekkannya dalam kehidupan sehari-hari sehingga mereka dapat memberikan kontribusi yang positif kepada lingkungannya (Kesuma, 2011). Pendidikan karakter tidak hanya untuk anak normal saja. Anak berkebutuhan khususpun perlu pendidikan karakter. Salah satu anak berkebutuhan khusus yang membutuhkan pendidikan karakter adalah anak autis. Pendidikan karakter dibutuhkan anak autis sebagai bekal dalam hidupnya sehingga siap menghadapi segala tantangan di dunia yang penuh persaingan dengan penuh percaya diri.

Autis merupakan suatu gangguan yang kompleks dimana anak tersebut umumnya mengalami tiga bidang kesulitan yaitu komunikasi, imajinasi, dan sosialisasi (Baihaqi, 2006). Ditinjau dari segi perilaku, anak autis cenderung melukai dirinya sendiri, tidak percaya diri, bersikap agresif, menanggapi secara kurang atau berlebihan terhadap suatu stimuli eksternal, dan menggerak-gerakkan anggota tubuhnya secara tidak wajar (Maulana, 2007). Anak autis memiliki sejumlah gangguan kualitatif dalam berkomunikasi salah satunya adalah kemampuan untuk memulai atau melanjutkan pembicaraan dengan orang lain meskipun dalam percakapan yang sederhana (Peeters: 2009).

\footnotetext{
"Corresponding author.

E-mail addresses: endangsumarti@yahoo.com (Endang Sumarti)
}

ISSN : 2579-3799 (Online) - BASINDO : Jurnal Kajian Bahasa, Sastra Indonesia, dan Pembelajarannya is licensed under Creative Commons Attribution-ShareAlike 4.0 International License (http://creativecommons.org/licenses/BY/4.0/).

82 | BASINDO : Jurnal Kajian Bahasa, Sastra Indonesia, dan Pembelajarannya 
Jumlah anak Indonesia yang menyandang autis terus bertambah meskipun penyebabnya masih misterius. Sampai saat ini kalangan medis di Indonesia belum punya standar penanganan baku untuk menangani anak autis. Meningkatnya jumlah anak autis merupakan persoalan yang menjadi tanggung jawab bersama, bukan hanya tanggung jawab medis atau psikolog saja. Pendidikan juga memainkan peran untuk mengarahkan mereka menjadi manusia-manusia yang mandiri dan bermanfaat sesuai dengan kemampuannya agar tidak menjadi beban bagi lingkungan di sekelilingnya.

Salah satu cara penanaman pendidikan karakter pada anak autis bisa dilakukan melalui dongeng. Dongeng merupakan media efektif untuk menanamkan nilai pendidikan karakter kepada anak termasuk anak autis. Melalui dongeng guru, orang tua, dan masyarakat dapat melakukan transformasi nilai melalui perilaku dan karakter tokoh dalam cerita. Misalnya nilai-nilai kejujuran, rendah hati, kesetiakawanan, maupun tentang berbagai kebiasaan sehari-hari seperti pentingnya makan sayur dan menggosok gigi. Salah satu keberhasilan suatu dongeng ditentukan oleh kemampuan pendongeng untuk menyajikannya secara menarik.

Berdasarkan latar belakang di atas, penulis tertarik untuk menulis tentang Pendidikan Karakter Anak Autis melalui Dongeng.

\section{A. Pembahasan}

\section{Pendidikan Karakter}

Pendidikan karakter merupakan usaha yang dilakukan oleh para personil sekolah, bahkan dilakukan bersama-sama dengan orang tua dan anggota masyarakat untuk membantu anak-anak dan remaja agar memiliki sifat peduli, berpendirian, dan bertanggung jawab. Pendidikan karakter adalah sebuah proses transformasi nilai-nilai kehidupan untuk ditumbuhkembangkan dalam kepribadian seseorang sehingga menjadi satu dalam perilaku kehidupan orang itu (Majid, 2011). Secara sederhana, pendidikan karakter dapat didefinisikan sebagai segala usaha yang dapat dilakukan untuk mempengaruhi karakter siswa (Jumadi, 2018). Lickona (1992) menyatakan bahwa pengertian pendidikan karakter adalah suatu usaha yang disengaja untuk membantu seseorang sehingga ia dapat memahami, memperhatikan dan melakukan nilai-nilai etika. Menurut Lickona, karakter berkaitan dengan konsep moral (moral knonwing), sikap moral (moral felling), dan perilaku moral (moral behavior). Berdasarkan ketiga komponen ini dapat dinyatakan bahwa karakter yang baik didukung oleh pengetahuan tentang kebaikan, keinginan untuk berbuat baik, dan melakukan perbuatan kebaikan.

Pendidikan karakter merupakan salah satu usaha untuk mendidik anak-anak agar dapat mengambil keputusan dengan bijak dan mempraktekkannya dalam kehidupan sehari-hari sehingga mereka dapat memberikan kontribusi yang positif kepada lingkungannya (Kesuma, 2011). Pendidikan karakter pada prinsipnya adalah upaya untuk menumbuhkan kepekaan dan tanggung jawab sosial, membangun kecerdasan emosional dan mewujudkan siswa yang memiliki etika tinggi (Barnawi, 2012). Pendidikan karakter memerlukan metode khusus yang tepat agar tujuan pendidikan dapat tercapai. Diantara metode pembelajaran yang sesuai adalah metode keteladanan, metode pembiasaan, dan metode pujian dan hukuman.

Berdasarkan beberapa pendapat di atas dapat disimpulkan bahwa pendidikan karakter dapat dimaknai sebagai pendidikan nilai, pendidikan budi pekerti, pendidikan moral dan pendidikan watak yang bertujuan mengembangkan kemampuan peserta didik untuk memberikan keputusan baik buruk, memelihara apa yang baik, mewujudkan, dan menebar kebaikan itu dalam kehidupan sehari-hari.

\section{Pengertian anak autis}

Autis berasal dari kata auto yang berarti sendiri. Istilah autisme, diperkenalkan sejak 1943 oleh Kanner untuk menghormati penemunya, autisme disebut juga sindroma Kanner, yakni sindroma dengan gejala tidak mampu bersosialisasi, kesulitan menggunakan bahasa, berperilaku berulang-ulang, serta bereaksi tidak biasa terhadap rangsangan disekitarnya (Handojo, 2004; Yatim, 2003). Dalam Diagnostic and Statistical manual Fourth Edition (DSM IV), autisme ditempatkan di bawah kategori gangguan perkembangan pervasif antara retardasi mental dan gangguan perkembangan spesifik. Autisme adalah gangguan perkembangan yang mengganggu perkembangan interaksi sosial, perilaku, dan bahasa penyandangan. Autisme bukan gangguan mental dan tidak disebabkan oleh trauma. Autisme merupakan ganguan neurobiologi kompleks. (Peeters, 2004; Puspita, 2004).

Autisme merupakan gangguan perkembangan khusunya terjadi pada masa anak-anak yang membuat seseorang tidak mampu mengadakan interaksi sosial dan seolah-olah hidup dalam dunianya sendiri. Autisme merupakan salah satu kelompok dari gangguan pada anak yang ditandai munculnya gangguan dan keterlambatan dalam bidang kognitif, komunikasi, ketertarikan pada interaksi sosial, dan perilaku. Dalam bahasa Yunani kata autis, "auto" berarti sendiri ditujukan kepada seseorang ketika dia 
menunjukkan gejala "hidup dalam dunianya sendiri atau mempunyai dunia sendiri". Autis memang merupakan kelainan perilaku yang penderitanya hanya tertarik pada aktivitas mentalnya sendiri (Prasetyono, 2008; Veskarisyanti, 2008).

Gejala autisme sudah tampak sebelum anak mencapai usia tiga tahun. Autis merupakan gangguan perkembangan yang berat pada anak. Perkembangan mereka menjadi terganggu terutama dalam komunikasi, interaksi, dan perilaku. Autisme adalah suatu gangguan neurobilogis yang terjadi pada anak di bawah tiga tahun. Gangguan yang tampak adalah gangguan dalam bidang perkembangan, perkembangan interaksi dua arah, perkembangan timbal balik, dan perkembangan perilaku. Gangguan perilaku pada anak autisme bercirikan kurang dalam bersosialisasi resiprokal, kekacauan dalam berkomunikasi verbal dan nonverbal, serta perilaku repetitif. (Maulana, 2007).

Anak-anak dengan gangguan autistik biasanya kurang dapat merasakan kontak sosial. Mereka cenderung menyendiri dan menghindari kontak dengan orang. Orang dianggap sebagai objek (benda) bukan sebagai subjek yang dapat berinteraksi dan berkomunikasi. Autistik merupakan gangguan perkembangan yang mempengaruhi beberapa aspek bagaimana anak melihat dunia dan bagaimana belajar melalui pengalamannya. Autis adalah salah satu dari lima tipe gangguan perkembangan pervasif atau pervasif developmen disorder (PDD), yang ditandai tampilnya abnormalitas pada domain interaksi sodial dan komunikasi (Yuwono, 2009; Priyatna, 2010).

Dari berbagai definisi di atas dapat disimpulkan bahwa autisme adalah sindroma dengan gejala penyimpangan komunikasi, sosialisasi, dan kognisi, yang dialami seseorang dalam perkembangannya. Anak autis adalah individu dengan suatu kondisi ketidakmampuan untuk menampilkan keselarasan antara emosi atau perilaku dalam berkomunikasi dan berinteraksi dengan lingkungan yang dapat diterima secara umum sesuai dengan norma-norma yang berlaku di masyarakat.

\section{Karakteristik anak autis}

Karakteristik anak autis antara lain tidak peduli dengan lingkungan sosialnya, tidak bisa bereaksi normal dalam pergaulan sosialnya, perkembangan bicara dan bahasa tidak normal, dan reaksi atau pengamatan terhadap lingkungan terbatas atau berulang-ulang. Selain itu anak autis cenderung menghindari kontak mata dengan orang lain, termasuk dengan sang ibu, senang melihat mainan berputar dan digantung di atas tempat tidur, terlambat bicara dan bahasanya tidak dimengerti orang lain, tidak mau bila dipanggil namanya, cenderung tidak mempunyai rasa empati, dan merasa tidak nyaman bila memakai pakaian dengan bahan kasar. Anak autis memiliki ciri khusus antara lain adalah suara yang bergaung, rasa takut untuk disentuh, berjalan di atas ujung kaki, memutar-mutar tubuh seperti gasing, melompat-lompat, dan meniru kata-kata. Beberapa anak autistik tidak mampu berbicara, tidak mampu mengekspresikan diri, baik melalui bahasa verbal maupun nonverbal, terlihat sangat asyik dengan dirinya sendiri, minatnya terbatas, dan sama sekali tidak tertarik dengan lingkungannya. Kekebalan tubuh tidak berkembang sebagaimana seharusnya, berinteraksi jika membutuhkan sesuatu, berkomunikasi dengan tertawa dan menangis, sangat hiperaktif, tidak mau digandeng di tempat umum, menolak diarahkan, bahkan menolak disentuh, dan dipegang (Yatim, 2003; Puspita, 2004) .

Menurut Handojo, (2004); Peeters, (2004); Peeters, (2009); Prasetyono (2008) kriteria gangguan autistik dalam DSM-IV dipaparkan berikut ini.

A. Harus ada sedikitnya enam gejala dari (1), (2), dan (3) dengan minimal dua dari gejala (1) dan masing-masing satu dari gejala (2) dan (3).

(1) Gangguan kualitatif dalam interaksi sosial yang timbal balik. Mnimal harus ada dua gelaja dari gejala-gejala di bawah ini.

a. Tak mampu menjalin interaksi sosial yang cukup memadai: kontak mata sangat kurang, eksprsi muka kurang hidup, gerak-gerik yang kurang tertuju.

b. Tak bisa bermain dengan teman sebaya.

c. Tak dapat merasakan apa yang dirasakan orang lain.

d. Kurangnya hubungan sosial dan emosional yang timbal balik.

(2) Gangguan kualitatif dalam bidang komunikasi seperti ditujukkan oleh minimal satu dari gejalagejala di bawah ini:

a. Bicara terlambat atau bahkan sama sekali tidak berkembang (dan tidak ada usaha untuk mengimbangi komunikasi dengan cara lain tanpa bicara).

b. Bila bisa bicara, tidak dipakai untuk berkomunikasi.

c. Sering menggunakan bahasa yang aneh dan diulang-ulang.

d. Cara bermain kurang variatif, kurang imajinatif, dan kurang bisa meniru.

(3) Suatu pola yang dipertahankan dan diulang-ulang dari perilaku, minat, dan kegiatan. Sedikitnya harus ada satu dari gejala di bawah ini. 
a. Mempertahankan satu minat atau lebih dengan cara yang sangat khas dan berlebih-lebihan.

b. Terpaku pada suatu kegiatan ritualistik atau rutinitas yang tidak ada gunanya.

c. Ada gerakan-gerakan aneh yang khas dan diulang-ulang.

d. Seringkali sangat terpukau pada bagian-bagian benda.

B. Sebelum umur tiga tahun tampak adanya keterlambatan atau gangguan dalam bidang:

a. Interaksi sosial.

b. Berbicara dan berbahasa.

c. Cara bermain yang kurang variatif.

C. Bukan disebabkan oleh sindrom Rett atau gangguan disintegratif masa kanak-kanak

Selain itu karakteristik anak autis antara lain tidak tampak tanda-tanda perkembangan bahasa, kadang-kadang mengeluarkan suara tanpa arti. Gangguan interaksi sosial yaitu anak mengalami kegagalan untuk bertatap mata, ketidakmampuan untuk secara spontan mencari teman untuk berbagi kesenangan, dan ketidakmampuan anak untuk berempati. Aktivitas, perilaku, dan ketertarikan anak terlihat sangat terbatas. Sangat sensitif terhadap sentuhan, tidak sensitif terhadap rasa sakit dan rasa takut. Menyenangi benda-benda yang berputar, tidak suka bermain seperti anak-anak pada umumnya, dan dengan anak sebayanya. Sering marah-marah tanpa alasan yang jelas, tertawa-tawa, menangis tanpa alasan, temper tantrum, kadangkadang suka menyerang dan merusak, berperilaku yang menyakiti dirinya sendiri, serta tidak mempunyai empati yang tidak mengerti perasaan orang lain. (Maulana, 2007; Veskarisyanti, 2008; Prasetyono, 2008).

Berbagai karakteristik autisme yang telah dijabarkan di atas dapat disimpulkan bahwa karakteristik autisme dapat dikelompokkan berdasarkan (1) isu berbicara, meliputi tidak mampu berbicara, tidak mampu bersuara, membeo; (2) isu interaksi, meliputi kurang berinteraksi dalam kelompok, kurang kontak mata, tampak tidak bekesadaran terhadap kehadiran orang lain; (3) isu perilaku, meliputi tidak tertarik sentuhan/berdekatan, asyik dengan gerakan tangan; berputar-putar, diulang-ulang; menyakiti diri sendiri, berperilaku rutin; (4) isu sensori, meliputi tidak suka suara-suara tertentu, tekstur dan atau rasa tertentu, tidak suka disentuh, sangat pasif, menutup telinga terhadap gangguan suara yang keras, (5) kemampuan khusus meliputi menggambar, musik, matematika, (6) penanda biologis meliputi bermasalah pada makanan, beberapa anak menderita gangguan tidur.

\section{Pendidikan Karakter Anak Autis melalui Dongeng}

Pendidikan karakter kini diberikan di semua jenjang pendidikan termasuk anak berkebutuhan khusus. Hal ini dilakukan karena pemerintah melihat masyarakat Indonesia dari segi moral saat ini sangat memprihatinkan. Anak autis termasuk anak berkebutuhan khusus sehingga perlu mendapatkan pendidikan karakter. Pendidikan karakter perlu diberikan kepada anak autis dengan harapan mampu mewujudkan anak autis yang berkarakter sesuai dengan nilai-nilai budaya dan agama seperti halnya anak-anak normal.

Nilai agama diberikan kepada anak autis sebagai salah satu cara agar mengenal Tuhan. Anak autis akan mengetahui apa yang diperintahkan dan apa yang dilarang Tuhan melalui pendidikan karakter dalam penanaman nilai agama. Pendidikan karakter berkaitan dengan nilai budaya kepada anak autis lebih diarahkan untuk memberikan contoh pada nilai-nilai tertentu seperti kesetiakawanan, rasa hormat, disiplin, jujur, adil, peduli, dalam kehidupan sehari. Selain nilai agama dan budaya anak autis juga perlu pendidikan karakter berkaitan dengan nilai moral, misalnya sikap berani, tanggung jawab, tolong menolong, saling bahu membahu sesama teman.

Mengingat anak autis mengalami gangguan dalam komunikasi dan interaksi sosial maka penanaman nilai pendidikan karakter anak autis disesuaikan dengan kondisi mereka. Salah satu cara penanaman nilai pendidikan karakter anak autis dilakukan melalui dongeng. Dongeng merupakan media efektif untuk menanamkan nilai pendidikan karakter kepada anak autis.Dongeng merupakan bentuk sastra lama yang bercerita tentang suatu kejadian yang luar biasa yang penuh khayalan (fiksi) yang dianggap oleh masyarakat suatu hal yang tidak benar-benar terjadi. Dongeng merupakan bentuk cerita tradisional atau cerita yang disampaikan secara turun-temurun dari nenek moyang. Dongeng berfungsi untuk menyampaikan ajaran moral (mendidik), dan juga menghibur.

Mendongeng merupakan salah satu ketrampilan yang harus dikuasai oleh orang tua, guru dan juga terapis. Agar anak autis tertarik kepada dongeng yang dibacakan tentunya cara mendongeng harus menarik. Kalau mendongengnya dengan cara yang biasa, kaku, tidak berekspresi tentunya akan membosankan dan anak tidak tertarik dengan dongeng yang disampaikan. Kalau anak autis sudah tidak tertarik dengan dongeng yang dibacakan pesan moral yang terkandung dalam dongeng tidak akan sampai pada anak. Oleh karena itu agar pesan yang disampaikan dalam dongeng bisa dipahami anak autis, dongeng harus disampaikan dengan cara yang menarik, luwes, dan penuh ekspresi. 
Semua anak senang mendengarkan dongeng atau dibacakan cerita, termasuk anak autis. Saat mendengarkan dongeng atau dibacakan cerita, anak autis tampak seperti tidak peduli karena pada dasarnya mereka lebih tertarik kepada hal-hal yang bersifat visual. Oleh karena itu di dalam mendongeng atau bercerita kepada anak autis diperlupan teknik khusus agar mereka menaruh perhatian pada dongeng yang disampaikan. Melalui dongeng dilengkapi dengan media gambar sangat tepat untuk pendidikan karakter anak autis. Orang tua, guru, atau terapis bisa memodifikasi dongeng yang ingin disampaikan ke dalam beberapa bentuk fisik yang menarik, misalnya gambar berukuran besar.

Dongeng sangat bermanfaat dalam pendidikan karakter anak autis. Melalui dongeng berbagai pesan moral dapat disampaikan kepada anak autis. selain itu perbendaharaan kata anak akan semakin banyak karena anak autis akan mendapatkan kosa kata baru dalam setiap dongeng yang disampaikan kepadanya. Kedekatan dan hubungan emosional antara anak autis dengan orang tua, guru, dan terapis terjalin lebih intim. Semua anak senang bila mendengarkan dongeng, termasuk anak autis. Anak autis tampak seperti tidak peduli ketika dibacakan dongeng. Hal ini karena anak autis lebih tertarik kepada halhal yang bersifat visual. Oleh karena itu, agar anak autis tertarik terhadap dongeng yang disampaikan diperlukan teknik khusus dalam mendongeng dan media yang sesuai untuk anak autis.

Beberapa media yang cocok digunakan untuk mendongeng bagi anak autis adalah menggunakan media gambar, menggunakan boneka, atau menggunakan boneka jari. Mendongen menggunakan media boneka jauh lebih baik karena bentuknya tiga dimensi dan dapat disentuh oleh anak. Mendongeng dengan menggunakan boneka selain menyampaikan isi dongeng, sekaligus melatih sensori sentuhan anak autis. selain boneka untuk menyampaikan dongen kepada anak bisa dilakukan melalui media gambar. Gambar yang digunakan untuk media dongeng sebaiknya menggunakan gambar berukuran besar dengan harapan anak autis bisa melihat dengan jelas. Agar gambar tampak lebih menarik digunakan gambar yang berwarna dan disampaikan penuh ekspresi. Selain menggunakan media di atas, yang perlu dipertimbangkan dalam menyampaikan dongeng kepada anak autis adalah isi dongeng harus disesuai dengan anak autis.

Dongeng yang diberikan kepada anak autis adalah dongeng mengajarkan anak akan hal-hal yang dekat dengan kehidupan mereka sehari-hari. Misalnya cerita tentang bagaimana berperilaku yang baik di tempat umum. Pendidikan karakter melalui dongeng dengan harapan agar anak autis bisa berkembang dan menjadi pribadi yang utuh dan mandiri.

\section{Simpulan}

Berdasarkan uraian di atas dapat disimpulkan bahwa pendidikan karakter sangat penting untuk membentuk kepribadian anak autis. Nilai-nilai pendidikan karakter yang perlu diberikan kepada anak autis meliputi nilai agama, nilai-nilai kepribadian, nilai moral, dan nilai budaya. Dongeng merupakan salah satu media yang cocok untuk menanamkan nilai pendidikan karakter kepada anak autis. Melalui dongeng tentang kisah-kisah keteladanan, diharapkan anak autis memiliki landasan untuk mengubah pribadi, bangsa, dan negara kearah yang lebih baik.

\section{DAFTAR RUJUKAN}

Baihaqi, MIF. (2006). Memahami dan Membantu Anak ADHD. Bandung: Refika Aditama.

Barnawi dan M. Arifin. (2012). Strategi dan Kebijakan Pembelajaran Pendidikan Karakter. Jogjakarta: ArRuzz Media

Handojo. (2004). Autisma: Petunjuk Praktis dan Pedoman Materi Untuk Mengajar Anak Normal, Autis dan Perilaku Lain. Jakarta: Buana Ilmu Populer.

Jumadi, J. (2018). Mengntensifkan Peran Pendidikan Sastra untuk Membagun Karakter Siswa. BASINDO: jurnal kajian bahasa, sastra Indonesia, dan pembelajarannya, 1(2), 31-39.

Kesuma, Dharma, dkk. (2011). Pendidikan Karakter: Kajian Teori dan Praktik di Sekolah. Bandung: Rosdakarya

Koesoema, A. (2007). Pendidikan Karakter: Strategi Mendidik Anak di Zaman Global. Jakarta: PT Grasindo

Lickona, Thomas. (1992). Educating For Character: How Our School Can Teach Respect and Responsibility. New York: Bantam Books.

Majid, A dan Andayani, D. (2011). Pendidikan Karakter Perspektif Islam. Bandung: Remaja Rosda Karya.

Maulana, M. (2007). Anak Autis: Mendidik Anak Autis dan Gangguan Mental Lain Menuju Anak Cerdas dan Sehat. Jogjakarta: Ar-Ruzz Media

86 | BASINDO : Jurnal Kajian Bahasa, Sastra Indonesia, dan Pembelajarannya 
Peeters, T. (2004). Autisme: Hubungan Pengetahuan Teoritis dan Intervensi Pendidikan Bagi Penyandang Autis. Jakarta: Dian Rakyat.

Peeters, T. (2009). Panduan Autisme: Hubungan Antara Pengetahuan Teoritis dan Intervensi Pendidikan Bagi Penyandang Autis. Jakarta: Dian Rakyat.

Prasetyono, D. S. (2008). Serba Serbi Anak Autisn (Autisme dan Gangguan Psikologis Lainnya: mengenal, menangani, dan Mengatasinya dengan Tepat dan Baik). Jogjakarta: DIVA Press.

Priyatna, A. (2010). Amazing Autism: Memahami, Mengasuh, dan mendidik Anak Autis. Jakarta: Gramedia.

Puspita, D. (2004). Untaian Duka Tabuaran Mutiara (Hikmah Perjuangan Ibunda Untuk Anak Autistik). Bandung: Qanita.

Veskarisyanti, G. A. (2008). 12 Terapi Autis Paling Efektif dan Hemat: Untuk Autisme, Hiperaktif, dan Retardasi Mental. Yogyakarta: Pustaka Anggrek.

Yatim, F. (2003). Autisme: Suatu Gangguan Jiwa pada Anak-anak. Jakarta: Pustaka Populer Obor.

Yuwono, J. (2009). Memahami Anak Autistik: Kajian Teori dan Empirik. Bandung: Alfabeta.

87 | BASINDO : Jurnal Kajian Bahasa, Sastra Indonesia, dan Pembelajarannya 